\title{
s. \\ BRAZILIAN JEITINHO VERSUS CHINESE GUANXI: INVESTIGATING THEIR INFORMAL INFLUENCE ON INTERNATIONAL BUSINESS
}

\begin{abstract}
CLÁUDIO V. TORRES*
Ph.D. in Industrial Organizational Psychology of California School of Professional Psychology of University of California San Diego. Professor adjunto do Departamento de Psicologia Social e do Trabalho da Universidade de Brasília (UnB). Campus Darcy Ribeiro, Asa Norte, Instituto de Psicologia, Departamento Psicologia Social e do Trabalho, Brasília - DF - Brasil - CEP 70910-900 E-mail: claudio.v.torres@gmail.com

\section{SOLANGE ALEINITO}

Doutora em Psicologia Social e do Trabalho pelo Instituto de Psicologia da Universidade de Brasília (UnB). Professora adjunta do Programa de Pós-Graduação em Administração da Universidade de Brasília (PPGA-UnB).

Campus Darcy Ribeiro, Prédio da Face, Departamento de Administração, sala AT 61/7, Asa Norte, Brasília - DF - Brasil - CEP 70910-900 E-mail: salfinito@unb.br

\section{CÉSAR AUGUSTO DE SOUZA PINTO GALVÃO}

Graduado em Psicologia pelo Instituto de Psicologia da Universidade de Brasília (UnB). Analista técnico-administrativo da Escola de Administração Fazendária do Ministério da Fazenda. Rodovia DF-001, Km 27,4, Setor de Habitações Individuais Sul, Brasília - DF - Brasil - CEP 71686-900 E-mail: cesaraugusto.galvao@gmail.com

\section{BRUNA CHIE YIN TSE}

Bacharel em Relações Internacionais pela Faculdade de Ciências Aplicadas da Universidade de Brasília (UnB). Analista técnico-administrativo do Ministério das Cidades. Setor de Autarquias Sul, Quadra 01, Lote 01/06, Bloco "H", Ed. Telemundi II, $11^{\circ}$ andar, sala 1105, Asa Sul, Brasília - DF - Brasil - CEP 70070-010

E-mail: brunatse@gmail.com

* Sponsored by the Conselho Nacional de Desenvolvimento Científico e Tecnológico (CNPq), with a productivity grant to the author.

Este artigo pode ser copiado, distribuído, exibido, transmitido ou adaptado desde que citados, de forma clara e explícita, o nome da revista, a edição, o ano e as páginas nas quais o artigo foi publicado originalmente, mas sem sugerir que a RAM endosse a reutilização do artigo. Esse termo de licenciamento deve ser explicitado para os casos de reutilização ou distribuição para terceiros. Não é permitido o uso para fins comerciais.
\end{abstract}




\section{ABSTRACT}

The Brazilian jeitinho and the Chinese guanxi are considered indigenous forms of informal influence. The first can be described as behavior tactics aimed at resolving social problems. The latter is broadly described as achieving goals through the use of social networks. These influence processes were chosen because they are commonly used in business negotiations in Brazil and China. Thus, understanding their peculiarity is fundamental for the management of organizations involved in business in those two cultures. Therefore, we seek to determine whether such influence processes differ, as it is possible that a process said to be indigenous to a particular cultural context might be, in fact, also found elsewhere. To investigate their uniqueness and the relationship between them, two studies were carried out. In both studies, participants rated representativeness, typicality and positivity of social scenarios, besides completing a 2I-item version of the Schwartz's Portrait Value Survey and a scale regarding attitudes towards corruption. Data were analyzed by a series of mean difference tests and stepwise regressions, separately for each nation, and the results are presented by sample. There were two samples: university students' sample (with 266 Brazilian and 220 Chinese) and managers' sample (with IOI Singapore Chinese and 246 Brazilian). Brazil scored significantly higher on conservation and selfenhancement values when compared to China. Chinese respondents perceived the guanxi scenarios as more typical of what happens in China than the jeitinho scenarios, with a reverse pattern being observed for Brazilians. Although Brazilian respondents evaluated jeitinho less positively than Chinese respondents evaluated guanxi scenarios, but they also did perceive jeitinho as more positive than. For the managers' samples, it was observed that Brazilians had a significantly lower score on attitudes toward business corruptibility when compared to Chinese managers. Stepwise regressions suggest that positivity is linked with business corruptibility for each respective scenario type by nation. 


\section{KEYWORDS}

Cross-cultural management. Informal influence. Corruptibility. International business. Brazilian jeitinho.

\section{INTRODUCTION}

Scholars interested in making comparisons between cultures have been using the individualism-collectivism dimensions of cultural variations as predictors in their studies. Typically, such scholars treat collectivism as a single, unified cultural manifestation, addressing little or no variation amongst collectivists, or allocentric individuals (Triandis, I994). Yet, when we consider that the literature on collectivism includes quite distinct countries, such as Japan, the Philippines, or Egypt, it is easy to assume that individuals in those countries should present different expressions of collectivism.

The indigenous psychology literature has pointed out ways in which people exhibit such variations in collectivism expression; one being the type of informal influence process typically used by individuals in those societies. Researchers have identified distinctive forms of interpersonal influence in collectivistic cultures (Amado \& Vinagre Brasil, I99I; Aycan, 2008a; Xin \& Pearce, I996). Smith, Huang, Harb, and Torres (2OI2) suggest that forms of indigenous influences have mostly been proposed by researchers located within more collectivistic cultures, because most forms used to describe informal influence processes have originated within Individualistic cultures. Examples of indigenous informal influence processes are the Amae in Japan, or the Wasta in Muslin countries.

This study investigated two influence processes identified as indigenous by the international literature of collectivistic cultures, the Brazilian jeitinho and the Chinese guanxi. We seek to determine whether such influence processes differ, as it is possible that a process said to be indigenous to a particular cultural context is, in fact, may also be found elsewhere. We argue that the values endorsed by Brazilian and Chinese respondents do correlate with their perception of jeitinho or guanxi as representative and typical in their country.

These influence processes were chosen because they are commonly used in business negotiations in Brazil and China, two countries of the Bric group. The Bric countries (also known as the Big Four) is a grouping acronym adopted by the economics literature (O'Neill, 200I) that refers to the countries of Brazil, Russia, India, and China, all considered to be in a similar stage of advanced economic 
development. Due to this, they became a symbol of the shift in global economic power from the developed (Western) countries, towards the developing world. Together, these countries represent over $25 \%$ of the world's land coverage, and over $40 \%$ of the world's population. According to the Bric thesis, these countries are divided into two groups: those which will become in a near future the world's dominant suppliers of manufactured goods and services, such as China, and those which will become similarly dominant as suppliers of raw materials, as Brazil (Kobayashi-Hillary, 2007). Undoubtedly, these countries are among the biggest and fastest growing economies in the world (Vercueil, 20I0), and should be taken as important business opportunities. Furthermore, jeitinho and guanxi were chosen because they represent influence processes that occur in countries other than Japan and Mexico, commonly used as examples of collectivistic cultures in cross-cultural comparisons. Thus, studies about the indigenous forms of influence in such cultures may contribute towards the success of business negotiations in these countries, which are less investigated in comparative tests by the mainstream North American psychology.

\subsection{INFORMAL INFLUENCE PROCESSES: JEITINHO AND GUANXI}

Different forms of informal influence processes have been proposed in the literature as indigenous (Smith et al., 20I2), among which, the jeitinho (little way) (Barbosa, I995) and guanxi (connections) (Chen \& Chen, 2004). Such processes are detailed as follows.

The jeitinho is described to be a strong characteristic of behavior in many segments of society in Brazil, including business organizations (Duarte, 2006), and it indicates creative ingenuity in rapidly achieving short-term solutions to problems (Smith et al., 20I2). There is no need for any kind of previous relationship between the parties involved in this process, both usually remaining as anonymous figures bounded only by one's necessity, and the other's power to grant it. The path to achieving the jeitinho may include ways of circumventing bureaucratic rules or ways of handling potential difficulties with superiors in a strongly hierarchical context.

In the Brazilian society, this process is described by Barbosa (I995) in the center of a continuum, in which the positive extreme approaches a favor-like action, while the negative approaches the idea of corruption. According to Barbosa (2006) and Smith et al. (2012), the differences between dar um jeitinho (to have a way out) and jeitinho brasileiro (Brazilian little way) suggest that the first expression can be explained as the solution to a problem no matter what, even 
when it seems that it cannot be solved through legal or official procedure. In this sense, dar um jeitinho has a negative connotation and its meaning closes to corruption. The second term, on the other hand, is seen as using creativity and pragmatism to deal with everyday events. Jeitinho brasileiro is understood as part of Brazilian national life and identity, having a positive connotation. This phenomenon is explicit and legitimate in the Brazilian society and may be used by everyone. As social hierarchy is well accepted in Brazilian culture, the use of jeitinho at different organizational levels is more a matter of magnitude than of incidence (Almeida, 2007).

Yet, for the use of the jeitinho, what matters most are not the laws or social status, but rather the rupture of hierarchy, leading towards equality and a positive and diffuse reciprocity. The decisiveness of succumbing or not to jeitinho lies greatly in the social abilities of the asking individual (the petitioner). It involves working through others on an egalitarian basis. In this sense, the jeitinho may open a gateway either to corruption or to establish social justice, privileging the human and natural aspects of each person rather than institutional and legal rights (DaMatta, I997). The effectiveness of the jeitinho relies deeply on factors that are opposite to those expected in a bureaucratic system, such as in Brazil (Torres \& Dessen, 2006). It has an intrinsic appeal to the emotional, rather than rational side of people. Jeitinho involves the use of behavioral tactics, such as excuses and justifications, where the reasoning is based on a personal situation that differentiates the person asking for the jeitinho from others in society.

The term jeitinho did not always carry such connotation. But the mission of tracing back its origins has proven to be almost impossible. The term was first made popular in the context of admiration for the dexterity of certain soccer players. The first official and written appearance of the term with this particular meaning is dated back to 1983 in the work of Ortência Bariani (DaMatta, I997). In her book Dicionário do Brasil (Dictionary of Brazil), the author incorporated the word jeitinho, as well as the expression dar um jeitinho, as a defining element of Brazilian social identity. In oral terms, the term is said to have been around since the I950s and the specific term jeitinho brasileiro has been traced back to the mid I950s. Yet, as jeitinho represents a social procedure implicitly learned, it does not actually have any specific systematic registering (Torres \& Dessen, 2008). It is embedded in the nucleus of Brazilian society, and is usually passed on by daily experienced situations, or oral tradition, throughout the generations in the country.

Guanxi (connections) has multiple meanings in the Mandarin language, such as concern, affect, matter, relation, relationship, and backdoor connections (Nitsch \& Diebel, 2007). Mainly, it relates to a relationship between common people and/or economic agents, with frequent or little interaction. Hwang 
(I997) describes it as a dyad interaction between a petitioner and a resource allocator, composed of two components: an expressive (affective), and an instrumental component, the distribution of which characterizesthe bond between them. For Luo (2000), guanxi represents the concept of drawing on connections (拉关系 la guānxi) in order to secure favors (人情 rénqíng) in personal relations. It forms an intricate pervasive relational network, which the Chinese cultivate energetically, subtly, and imaginatively. It contains implicit mutual obligation, assurances, and understanding, and it governs Chinese attitudes toward long-term social and business relationships. Broadly, guanxi means interpersonal linkages with the implication of continued exchange of favors.

Guanxi can be understood as a Cultural Standard, that is, the socially and accepted norms used by people in culture to assess their fellow citizens' behaviors (Thomas, 1999). Albeit the concept of Cultural Standard has not yet been profoundly investigated in the national literature, with rare exceptions (e.g., Teixeira \& Iwamoto, 20I3), its first development is attributed to Alexander Thomas in I99I (Deardorff, 2009). Cultural Standard, a term borrowed from the cognitive anthropologist Ward Goodenough (I964), is mostly directed used for intercultural training, especially of expatriates, touching simultaneously on different constructs, such as values, attitudes and behaviors (Teixeira \& Iwamoto, 2013), a discussion that goes beyond the scope of this paper. Suffice it to say that guanxi does have a quite practical application in management, and it has been described by Thomas and Schenk in 200I (see Zamor, 2008; Thomas \& Schenk, 200I) in cultural sensitizers as a Cultural Standard that is hierarchy-oriented, bureaucratic, and emphasizes etiquette and social harmony.

The establishment of guanxi by the parties includes a few characteristics, such as the direction of power relations (vertical or horizontal), level of intimacy, the congruence of goals, and the will to maintain harmony (Hwang, 1997). When achieving the goal through direct contact with the other party is not feasible, a third person, who shares guanxi with both sides, can serve as a mediator for the petitioner. Nitsch and Diebel (2007) described this process in five steps: gaining face, drawing connections, estimation of own benefit, the calculation of how much emotion is involved, and finally, the decision making. Once the petitioner and the resource allocator consider the characteristics of the guanxi, a rule of conduct should be chosen. For Ying (2002), this may result in three types of guanxi. The family guanxi, which follows the need rule; the helper guanxi, which follows the renqing (friendship) rule, that is, a social resource similar to a favor with pressing responsibility to repayment (Yang, 1957), with which one should consent in order to maintain social harmony (Gabrenya \& Hwang, I996). Ying (2002, p. 8) also points out to the guanxi involved in business and organized 
crime in China, which is considered to be "bad guanxi, even if not implicated with corruption", associated with favoritism, nepotism, unfair competition and fraud.

The basis of guanxi lies on the Confucian ethics (Nitsch \& Diebel, 2007), mainly on principle of respecting the superior, favoring an intimate person, as well as the maintenance of harmony. In the Confucian teachings, "everything will be accomplished smoothly in a harmonious family" (Hwang, I997, p. 22), with family being used as template for all other types relations within Chinese society (Chua, Morris \& Ingram, 2009). Ying (2002) also clarifies that one may use guanxi to bring benefits to his/her employer, but the person's guanxi network remains a personal property, rather than an organizational one. Face maintenance and the value of social harmony are highly related to the use of guanxi. As the violation of a social contract is understood as disrespect for the other party, the face maintenance of individuals may be at risk in a business negotiation (Liao \& Bond, 20II). Thus, another basis for the use of guanxi also follows Confucius' idea that "one should always put moral concerns before the pursuit of business interests" (Ying, 2002, p. IO).

\subsection{DEVELOPMENT OF HYPOTHESES}

Both influence processes have been identified and described in a collectivistic cultural context. However, they differ in some aspects, such as the hierarchical nature of relationship between the parties. In order to test their distinctiveness and similarities, theoretical distinctions should be inferred from their basis. While jeitinho represents an attempt to treat others equally, overcoming the barriers that may be present in a hierarchical society, guanxi accepts such hierarchical features, and uses them in its favor. Also, in the jeitinho process, no assumptions about a previous relationship between the parties involved is made, while the roots of guanxi follow the principle of long-term equity and maintenance of a long-term relationship. At the same time, both processes encompass a pragmatic use for solving problems. If both processes are implanted in the nucleus of their respective societies, being parcel and part of their cultural traditions, and embedded in the family structure of the individuals, then it is plausible to assume that:

- Hypothesis I: Respondents from Brazil and China will perceive scenarios derived from their nation as more representative of the local influence process than scenarios derived from the other nation.

Hypothesis I actually serves as a check that respondents from each nation will perceive that the scenarios used here do represent the concepts under 
investigation. However, it does not allow us to assume whether these scenarios describe typical instances occurring at a given site. If it is established that each concept is representative, then it is possible to observe whether they are distinctively typical of the processes that occur in each nation, permitting us to test if:

- Hypothesis 2: Brazilian and Chinese respondents will perceive scenarios derived from their nation as more typical of the influence processes that occur in their locations than are scenarios derived from the other nation.

It can be noted above the processes under evaluation may be viewed differently by their respective nationals. Despite the fact that both processes may not always be regarded as beneficial, it is informative to establish whether each indigenous process is perceived more positively than the other type. Although reliance on guanxi may harm others, it does not necessarily do so. Guanxi presumes affective attachment and deference between the parties, and behaviors that define guanxi, included giving one's supervisor birthday gifts. Failure to maintain a guanxi relationship will involve a mutual loss of face. Even as a defining element of Brazilian social identity, jeitinho also involves ways of achieving one's goals in ways that are quick and indirect. The rationale used in jeitinho does not necessarily follow a legal or official procedure. Therefore, it is plausible to test a twofold hypothesis:

- Hypothesis 3a: Respondents from each nation will evaluate scenarios derived from their nation more positively than scenarios derived from the other nation;

- Hypothesis 3b: Brazilian respondents will evaluate jeitinho scenarios less positively than Chinese respondents will evaluate guanxi scenarios.

If the typicality of scenarios is observed, and each locally-developed scenario is perceived by respondents to be a depiction of the influence process typically used in his or her culture, then we can assume that the informal influence processes in each national culture is a component of that culture. However, the perception and evaluation of an influence process is but an individual-level phenomenon, such as the level of analysis of measures used here. Thus, we should expect that the level of positivity attributed to a local scenario should be a function of the individual values endorsed by respondents of each country, which, in turn, should correspond to the individual values most prominent in each nation, as inferred from the participants sampled.

As noted in the processes' early descriptions, both jeitinho and guanxi include the idea of being part of national identity. Yet, at the same time, the rules 
of conduct or behaviors used in order to engage in one of these processes may carry a close notion of corruption. For instance, jeitinho is said to fluctuate between a favor and corruption, with unclear boundaries between them. In such sense, jeitinho may have a negative connotation. Whilst a main function of guanxi is the maintenance of group harmony, it may be also associated with favoritism, nepotism, and unfair competition, all of which carrying a strong link with corruption practices. Taken together, another twofold hypothesis may be tested:

- Hypothesis 4a: The values that predict scenario positivity will differ between nations.

- Hypothesis 4 b: For the managers' samples, scenario positivity will be predicted by the acceptance of business corruptibility.

\section{METHOD}

\subsection{PILOT STUDY}

To accomplish the purposes of this study, scenarios were developed describing in a few sentences influence events, involving a fictitious individual, that are said to have occurred in a specific context, either in Brazil or China. The context specificity of the scenarios posed a problem: college students are commonly used as participants in cultural comparisons studies. However, scholars suggest (e.g., Schwartz \& Bardi, 200I) that they may be less traditional in their values than the general population. Thus, a more traditional cultural group of participants would provide stronger evidence of distinctiveness between influence processes. As such processes are commonly used in the workplace, managers would be a good choice of participants. Yet, current trends toward the workforce globalization may as well attenuate the contrasts sought. In order to provide a more representative evidence of the intended cultural contrast between the two countries, two samples were chosen from the study, resulting in two sets of scenarios.

Both sets of scenarios were developed in each of the locally used languages (Portuguese and Chinese) and pilot tested within their country of origin. The procedure for the construction of scenarios was the same both for students and managers samples in Brazil and China. For instance, I2 scenarios describing influence events involving a student,which are said to have occurred in a context familiar to students. Another set of I2 scenarios was created involving a manager, which is said to have occurred in contexts familiar to managers. All scenarios were based in examples cited in the literature of the specific influence 
process (e.g., Barbosa, I995). For the students' scenarios, pilot test respondents were students in the same universities where the main study was conducted. For the managers' scenarios, pilot test respondents were located in the same nations in which the main study was to be conducted. Students were asked to rate on Io-point scales the extent to which each scenario was representative of the local influence process, whereas managers were asked to rate on 5-point scales the extent to which each of the pilot scenarios was representative of the local influence process. The 3 scenarios rated as most representative in each country and for each group (students vs. managers) were selected for the main study. For the students' sample, the mean representativeness of selected scenarios was 8.08 (China), and 7.53 (Brazil). For managers, the mean representativeness of selected scenarios was 4.93 (Brazil), and 4.33 (China).

\subsection{PARTICIPANTS}

The study counted on 220 Chinese university students and 266 Brazilian university students, all nationals by birth and studying in large universities. Also, the study included 246 Brazilian and Ior Singapore Chinese managers, all of whom were in full-time employment in the country of their nationality.

In terms of gender, $85 \%$ of Chinese were female, with an average of 2 I. 6 years old $(S D=2.3)$, while $53 \%$ of Brazilian students were female, with $2 \mathrm{I} .9$ years old ( $S D=5 . \mathrm{I})$. Demographic characteristics of managers were as follows: as regards to China, $47 \%$ of respondents were Chinese-Singaporeans women, with the mean age of 32.8 years $(S D=1.9)$, and a mean of 9.8 years working as a manager. As regards to Brazil, $55 \%$ of respondents were female managers, with an average age of 36 .I years old $(S D=2.3)$, and a mean of 9.5 years working as a manager. All managers were in full-time employment in the country of their nationality.

\subsection{MEASURES}

All respondents filled in a questionnaire that included, in the following order, a list of 6 scenarios to be rated in terms of representativeness, typicality, and positiveness; a 2I-item version of Schwartz's Portrait Value Survey (Schwartz et al., 200I); demographic questions. In the 2I-item version of Schwartz's Portrait Value, respondents were asked to evaluate on 6-point scales a series of persons embodying differing values. Response categories ranged from Very much like me to Not at all like me. The mean value of endorsement of all 2I items was also computed to provide a control for respondent acquiescence; as it is known that both acquiescent and extreme responding to Likert scales vary between national 
cultures (Smith, 2004). Responses to the 2I items, after computation, result in scores corresponding to each of Schwartz (I992) motivational types, i.e., the Mean Ratings Across Motivational Types (MRAT). These were then aggregated to yield scores for the 4 major domains of values identified by Schwartz et al. (200I). This enabled the verification as to whether each sample's profile resembled the typical profile for that nation as well as the testing of hypothesis $4 \mathrm{a}$.

Only in the case of managers' sample, attitudes toward business corruptibility were measured with the I4-item Intercultural Business Corruptibility Scale developed by Leong and Lim (2009). This scale entails a balanced set of items endorsing or rejecting business corruptibility, with 5-point response categories ranging from "Strongly agree" to "Strongly disagree".

As mentioned in the pilot study, scenarios were differently developed according to the sample (students or managers) under investigation. For the students, after the pilot testing was complete, minor modifications were made to ensure that the scenarios accorded with circumstances prevailing in the university contexts being sampled. The 6 selected scenarios were first translated into English, and then into the local language used at each of the sites (Portuguese or Chinese). They were also modified to disguise the place of origin of each scenario, by replacing the names of actors in the scenarios by local names of the same gender. There were equal numbers of male and female actors in the scenarios. The scenarios were then placed in the survey in randomized sequence. Also, the extent to which each scenario was perceived as representative of local influence process, it was rated by students on a 3 -point scale $(3=$ yes, $2=$ not sure, $I=n o)$, whereas typicality was rated on a 5 -point scale ( $\mathrm{I}=$ not at all typical, $5=$ very typical).

Similar procedures were taken for the translation and construction of managers' scenarios questionnaire, and for each of the 6 scenarios, respondents were asked to imagine that they themselves were the person who sought to achieve influence. However, for the managers' measure, the respondent rated the representativeness of the local influence process on a 5 -point scale $(5=$ definitely yes, $3=$ not sure, $\mathrm{I}=$ definitely no). The extent to which each scenario was perceived as typical of events like this around here was also rated on a 5 -point scale $(5=$ very typical, I = not at all typical).

Respondents' perceptions of scenario positivity were evaluated by four 5-point semantic differential ratings relating to each of the scenarios. The scales were happy-unhappy ( $\mathrm{I}=$ happy; $5=$ unhappy, subsequently reversed to give high scores for positive evaluations), unjustified-justified, embarrassed-unembarrassed, and proud-ashamed (reversed). These scales were designed in English and then back translated into local languages where necessary. Principal component analyses supported single-factor solutions for both sets of rating scales. Variance accounted for by single-factor solutions averaged $58 \%$ in both sets. 
Internal consistency estimates were also computed for ratings of each scenario set separately. Alpha was at $0.8 \mathrm{I}$ for Chinese responses and at 0.78 for Brazilian responses. Mean positivity scores were then calculated to form a single positivity score for each respondent's rating of each scenario.

\section{RESULts}

Results will be presented by sample studied, given the difference between their questionnaires. First, all results for the student sample will be shown, followed by findings obtained in the manager sample.

\subsection{STUDENTS" SAMPLE}

Responses to the portrait of values questionnaire (PVQ) were averaged to yield scores on the four major domains of values identified by Schwartz et al. (200I), after their correction for acquiescence was computed (MRAT). Such responses are provided in Table I. Brazil scored significantly higher on conservation and self-enhancement values, which agrees with the expectation that these samples would span the range defined by the concept of individualism-collectivism.

\section{TABLE I}

COMPARISON OF THE STUDENTS' SAMPLES

USING SCHWARTZ VALUE INDICES

\begin{tabular}{ccccc}
\hline & $\begin{array}{c}\text { SELF- } \\
\text { TRANSCENDENCE }\end{array}$ & OPENNESS TO CHANGE & SELF-ENHANCEMENT & CONSERVATION \\
\hline Brazil & $-.48(.51)$ & $-.41(.48)$ & $.39(.74)$ & $.49(.62)$ \\
\hline China & $-.45(.46)$ & $-.06(.57)$ & $.12(.51)$ & $.13(.69)$ \\
\hline & n.s. & $F=13.78 ; p<.001$ & $F=26.05 ; p<.001$ & $F=22.43 ; p<.001$ \\
\hline
\end{tabular}

Note: Means are adjusted for gender and acquiescence covariates.

Source: Elaborated by the authors.

First, it is necessary to establish the extent to which the selected scenarios are seen as representing the relevant influence processes, as predicted in hypothesis I. Table 2 shows that the mean representativeness of all scenarios was rated at or above 2.50 on the 3-point rating scale. Chinese respondents rated the Chinese scenarios as more representative of guanxi than the Brazilian scenarios 
$(p<.00 \mathrm{I})$. Brazilians rated the Brazilian scenarios as more representative of jeitinho than the Chinese scenarios $(p<$. II). Thus, the scenarios from both nations were seen as adequately representative of the relevant indigenous process.

Hypothesis 2 tests the extent to which respondents perceive that the indigenous processes exemplified by their scenarios is more typical of events in their culture than are the other scenarios. Table 2 also shows the means for typicality. Chinese respondents perceived the guanxi scenarios as more typical of what happens in China than the jeitinho scenarios $(p<.00 \mathrm{I})$. Brazilian respondents perceived the jeitinho as typical of what happens in Brazil $(p<.05)$.

TABLE 2

MEAN REPRESENTATIVENESS AND TYPICALITY OF SCENARIOS FOR STUDENTS AND MANAGERS

\begin{tabular}{clcc}
\hline & & JEITINHO & GUANXI \\
\hline \multirow{2}{*}{$\begin{array}{c}\text { Brazil } \\
\text { Representativeness }\end{array}$} & Managers & $\mathbf{4 , 1 2 * * ( . 8 0 )}$ & $3.94(1.03)$ \\
\cline { 2 - 4 } $\begin{array}{c}\text { Brazil } \\
\text { Typicality }\end{array}$ & Students & $\mathbf{2 . 4 9 * ( . 5 7 )}$ & $2.40(.59)$ \\
\cline { 2 - 4 } & Managers & $\mathbf{4 . 0 1 * * ( . 8 8 )}$ & $3.80(.91)$ \\
\hline China & Managers & $\mathbf{3 . 8 4 * ( . 8 4 )}$ & $3.36(.87)$ \\
\hline Representativeness & Students & $1.74(.56)$ & $\mathbf{3 . 8 6}(.79) * * *$ \\
\hline China & Managers & $3.08(.79)$ & $\mathbf{3 . 7 5}(. \mathbf{3 3}) * * *$ \\
\hline Typicality & Students & $3.24(.88)$ & $\mathbf{3 . 7 7}(. \mathbf{8 0}) *$ \\
\hline
\end{tabular}

Note: $* p<.05 ; * * p<.0$ I; $* * * p<.00$ I. For representativeness, students responded on a 3 -point scale, while managers responded on a 5-point scale.

Source: Elaborated by the authors.

Hypothesis 3 predicts how positively each scenario will be assessed. Hypothesis 3 a suggests that all respondents evaluate their national scenario more positively than the other-nation scenario, whereas hypothesis $3 \mathrm{~b}$ predicts that Brazilian students would evaluate jeitinho scenarios less positively than Chinese respondents would evaluate guanxi scenarios. The results presented in Table 3 indicate that hypothesis 3 was only partially confirmed. The table indicates that Chinese respondents perceived guanxi more positively than jeitinho $(p<.00 \mathrm{I})$. However, although Brazilian respondents did evaluate jeitinho less positively than Chinese respondents evaluated guanxi scenarios $(p<.05)$, Brazilians did 
not perceive jeitinho as more positive than guanxi. Actually, the response pattern was quite the opposite, with Brazilians evaluating guanxi more positively than jeitinho $(p<.05)$.

TABLE 3

MEAN POSITIVENESS OF SCENARIOS FOR STUDENTS AND MANAGERS

\begin{tabular}{clcc}
\hline & & JEITINHO & GUANXI \\
\hline \multirow{2}{*}{$\begin{array}{c}\text { Brazil } \\
\text { Positiveness }\end{array}$} & Managers & $1.92^{\mathrm{a}}(.57)$ & $\mathbf{2 . 3 6 * * ( . 7 7 )}$ \\
\cline { 2 - 4 } & Students & $2.20^{\mathrm{b}}(.74)$ & $\mathbf{2 . 6 7 * ( . 7 5 )}$ \\
\hline China & Managers & $2.55^{\mathrm{a}}(.67)$ & $\mathbf{3 . 1 9}(. \mathbf{5 4})$ \\
\hline Positiveness & Students & $2.62^{\mathrm{b}}(.65)$ & $\mathbf{2 . 9 0 ( . 7 2 ) * * *}$ \\
\hline
\end{tabular}

Note: $* p<.05 ; * * x<.01 ; * * * p<.00$ I between means in the same line. ${ }^{a, b}:$ Means in the same column with different superscripts differ from one another at $p<.05$.

Source: Elaborated by the authors.

Finally, hypothesis 4 a concerns the relations between respondents' values and how positively they evaluated their local scenarios. This was tested through a series of stepwise regressions, separately for each nation. At step I, gender was inputted as a control variable. At step 2, one of the value domains was inserted, and at step 3, an interaction between nation of the respondent and value domain was inputted. None of these regressions showed a significant explanation of the predictors.

\subsection{MANAGERS' SAMPLE}

Means and reliability estimates for the four major domains of values and for business corruptibility are provided in Table I. The scores for each nation were compared by a univariate analysis of covariance, with gender and age as covariates. As indicated in Table I, Chinese Singaporeans scored significantly higher on conservation values than respondents from the other sample, and significantly lower on self-transcendence than Brazilians. Brazilians scored significantly higher on self-transcendence and significantly lower on business corruptibility than the Chinese. There were no significant differences in openness to change values. Thus, the samples do vary from one another substantively. This makes it possible to test whether indigenous influence processes are distinctive. 
Preliminary analyses indicated no significant multivariate effects for gender, for responding by e-mail, for years worked and for acquiescent responding and these variables were therefore excluded from further analyses. Data analysis was conducted through multivariate analysis of covariance with nationality as the main independent variable, representativeness, typicality, and positivity as dependent measures, and age as a covariate. Significant effects were obtained for nationality with Pillai's Trace $\left(F(60,2688)=15.38 ; p<.001\right.$; partial $\left.\eta^{2}=.26\right)$ and for age $\left(F(15,669)=3.05 ; p<.001\right.$; partial $\left.\eta^{2}=.06\right)$.

First, it was necessary to establish the extent to which the scenarios derived from each nation are seen by local respondents as adequately representing the relevant influence process. As shown in Table 2, significant univariate effects of nationality on the representativeness were obtained for all scenarios. Table 2 also shows that the Brazilian and the Chinese mean representativeness of all scenarios were rated well above the midpoint on the 5-point rating scale. Brazilians rated the jeitinho scenarios as more locally representative than did the Chinese managers $(p<$. oI). The Chinese did see the guanxi scenarios as any more locally representative than did Brazilians. Thus, the scenarios from all nations were seen as adequately representative of the relevant indigenous process.

Hypothesis 2 tests the extent to which respondents perceived that the indigenous process exemplified by their scenarios is more typical of events in their culture than are the other scenarios. Table 2 shows significant univariate effects of nationality on the typicality of each type of scenario, as well as estimated marginal means for typicality. Brazilian respondents perceived the jeitinho scenarios as significantly more locally typical than did those from China $(p<$. oI). Chinese managers saw guanxi scenarios as significantly more typical than did Brazilians $(p<.00 \mathrm{I})$. Thus, there is support for the prediction that jeitinho is distinctive to Brazil, as guanxi is distinctive for China.

Positive evaluations of each type of scenarios were next examined. Table 3 shows significant univariate effects of nationality on positivity. Brazilians saw jeitinho scenarios as significantly less positive than did Chinese managers $(p<.00 \mathrm{I})$, and they also evaluated jeitinho less positively than Chinese managers evaluated guanxi scenarios. However, Chinese managers did not evaluate guanxi scenarios as significantly more positive than Brazilians did. Brazilians were most negative about both types of influence.

Hypotheses 4 relate to the prediction of local scenarios positiveness. Before testing such hypotheses, the mean index of business corruptibility was obtained for each sample. It was observed that Brazilians had a significantly lower score $(p<.0 \mathrm{I})$ on attitudes toward business corruptibility $(M=2.03$; $S D=0.49)$, when compared to Chinese managers $(M=2.79 ; S D=0.45)$ 
The relationship between respondents' values and scenarios positiveness was also tested by a series of stepwise regressions, in the same manner with regards to the students' samples. Again, none of the regressions computed showed a significant explanation of values on positivity, rejecting hypothesis $4 \mathrm{a}$. Hypothesis $4 \mathrm{~b}$ refers to the relation between mean endorsement of business corruptibility and scenario positivity. This was tested separately for each nation. Positivity was linked with business corruptibility for the respective scenario type by nation. For Brazilians, $2 \mathrm{I} \%(p<.00 \mathrm{I})$ of the variance in positivity of jeitinho scenarios was attributed by business corruptibility $\left(\beta=.25^{* * *}\right)$, whereas for Chinese managers sample, business corruptibility also predicted guanxi positiveness $\left(R^{2}=.19{ }^{* * * ;} ; \beta=.30 * * * *\right)$.

\section{DISCUSSION}

The results indicate that both informal influence styles were rated as representative of their local indigenous designation and typical of what occurs within their local cultural contexts. However, only jeitinho can fully satisfy the criterion of uniqueness. The jeitinho scenarios were perceived as significantly more typical by Brazilians than by the Chinese population sampled. More strikingly, guanxi was rated as more typical by Brazilians than by Chinese respondents. Thus, the majority of these influence processes must be considered culture-related rather than culture-bound.

The styles of influence exemplified by the scenarios used in this study were not popular with respondents, with very few mean ratings exceeding scale midpoints. Furthermore, the cultural distinctiveness of these styles is unrelated to their popularity. While there is evidence for the distinctiveness of jeitinho to Brazil, the Brazilian ratings of positivity were particularly low and lowest of all in respect of jeitinho. It is possible that this result had such an outcome because participants, managers, and students, assess jeitinho according to its negative definition, which is related to corruption, social and individual loss, as well as disbelief in the general contemporary Brazilian way of life (Barbosa, 2006). The distinctive Brazilian combination of frequent informal influence processes and their relatively lesser popularity underlines the need for distinctive Brazilian management practices (e.g., Tanure \& Duarte, 2005).

Cross-national surveys that involve the comparison of mean scores need to control known cultural differences in response style (Johnson, Kulesa, Cho, \& Shavitt, 2005; Smith, 2004). The inclusion of controls for acquiescence provides the necessary assurance of measurement validity. Given the known global distribution of acquiescent responding, it is likely that the present effects would have been stronger rather than weaker if controls had not been included. 
Both studies indicated that there are elements in common between informal forms of influence in widely varying cultural contexts. Rather than featuring different types of informal influence, national cultures appear to differ more in the frequency and intensity with which these processes occur. It is important to consider how these findings might contribute to a more universally valid model of influence within organizations. Guanxi mainly rests on a strong degree of relatedness between the parties involved. In contrast, mainstream models of influence have focused more on the effectiveness of formally appointed leaders (Aycan, 2008b; House et al., 2004). These approaches to the study of influence are not independent of one another, since relatedness can be an important element in the effectiveness of a formally appointed leader. Indeed, most published studies of guanxi have been focused on relations between superiors and their organizational subordinates (Chen, Friedman, Yu, Fang, \& Lu, 2009; Cheung, Wu, Chan, \& Wong, 2009; Yan \& Altman, 2009).

Influence based on relatedness entails the need to maintain and sustain the relationships that are involved. It is evident that in those locations where indigenous social influence processes have been proposed, indigenous ways of maintaining in-group relationships have also been identified. Within the nations currently sampled, we find models of face (Hwang \& Han, 20IO) and of honor (Gregg, 2005). These aspects of local cultures may sustain types of relationships within which influence processes identified as typical are constrained. In some cultures, influence may occur primarily in the context of hierarchy and of longterm relatedness. In other cultures, there may be more peer influence and more influence between strangers.

\subsection{IMPLICATIONS FOR PRACTICE}

This study indicates substantial commonality between the indigenous influence styles that were studied. However, this finding in no way undermines the utility of employing these concepts to understand aspects of organizational behavior in their locations of origin. On the contrary, it suggests that insights accomplished in one such setting may help to enlighten similar phenomena in a broader range of locations. By conducting multiple nation comparisons, we can best assess the validity of conclusions drawn from studies that have involved only one or at most two nations.

There is strong intolerance against discrimination enrooted within Brazilian society due to the historical myth of their mixed formation as a nation. It is believed and spread in various segments of society that blacks, whites and Indians joined together, each bringing a different characteristic that, equally bounded together, created Brazilian people. Therefore, Brazilians have adopted this image 
of being accepting, warm and tolerant people and any attempt to deviate from this image is frowned upon by society in general. Although pacifism is well seen, a major perceived acquiescence and, therefore, a lack of will to effectively change the present state of Brazil's public management is a possible consequence of this behavioral identity, which greatly favors the use of the jeitinho emotional and personal technique within organizations, but greatly reinforces its negative assessment when tending towards corruption.

Though this phenomenon can be considered rather recent in Brazilian history, it has gained major importance in society becoming today not only a constitutive part of everyone's daily life, but of Brazilian identity as a whole. The jeitinho importance lies in the fact that it is seen as a way to establish equality and social justice in an otherwise socially asymmetrical society. The social disparities encountered in this scenario are in many ways softened by the use of jeitinho. It allows each person to be seen as individuals or equal human beings free from social inequalities, expressing only a hierarchy of needs and the present situational inequality. Of course, we cannot disregard that its excessive usage, or its use in certain contexts might, in fact, have negative consequences and set solid bases for corruption.

Unlike the idea carried by some authors such as Guerreiro Ramos (Barbosa, 2006) that believe the jeitinho is bound to fade with further industrialization and development, it has persevered through the largest periods of industrialization and development and it has shown that it will most likely continue to play a central role in Brazilian society as an instrument of egalitarian treatment and social identity for years to come. Ying (2002) has a partially similar prospective for the future of guanxi, in which might be useful at the entry stage of a foreign company in China, but other factors will take over its importance later on.

\section{JEITINHO BRASILEIRO VERSUS GUANXI CHINÊS: INVESTIGANDO SUAS INFLUÊNCIAS INFORMAIS PARA NEGÓCIOS INTERNACIONAIS}

\section{RESUMO}

O jeitinho brasileiro e o guanxi chinês são considerados formas indígenas de influência informal. O primeiro pode ser descrito como tática de comportamento para resolver problemas sociais. O último é genericamente descrito como uma forma de alcançar objetivos mediante a utilização de redes sociais. Esses processos de influência foram escolhidos porque são comumente usados nas negociações comerciais realizadas no Brasil e na China. Assim, compreender suas peculia- 
ridades é fundamental para a gestão de organizações inseridas em negócios com essas duas culturas. Para tanto, procura-se determinar se esses processos são de influências diferentes, pois é possível que um processo originário de um contexto cultural particular também possa ser encontrado em outro lugar. Para investigar a singularidade e as relações entre eles, foram conduzidos dois estudos. Neles, os participantes avaliaram representatividade, tipicidade e positividade de cenários sociais, além de responderem ao questionário de valores pessoais (PVQ-2I) e a uma escala de atitude em relação à corrupção. Os dados foram analisados por testes de diferenças entre médias e regressões hierárquicas, separadamente para cada país, e os resultados apresentados por amostra. Foram duas amostras: uma amostra de estudantes universitários, com 266 brasileiros e 220 chineses; e uma amostra de gestores, com IoI chineses de Cingapura e 246 brasileiros. Os resultados para o Brasil foram significativamente maiores para os valores de conservação e autotranscendência, em comparação aos resultados da China. Os respondentes chineses perceberam os cenários guanxi como mais típicos quanto ao que acontece na China do que os cenários do jeitinho, e houve um padrão inverso para os respondentes brasileiros. Embora os brasileiros tenham avaliado o jeitinho menos positivamente do que os chineses avaliaram o guanxi, os brasileiros não perceberam o jeitinho como mais positivo que o guanxi. Para a amostra de gestores, observou-se que os brasileiros tiveram uma pontuação significativamente menor em atitudes ante a corrupção nos negócios quando comparados com os gestores chineses. Regressões hierárquicas sugerem que a positividade está associada à corrupção nos negócios para cada respectivo tipo de cenários por nação.

\section{PALAVRAS-CHAVE}

Gestão transcultural. Influência informal. Corrupção. Negócios internacionais. Jeitinho brasileiro.

\section{JEITINHO BRASILEÑO VERSUS GUANXI CHINO: UNA INVESTIGACIÓN DE SU INFLUENCIA INFORMAL PARA LOS NEGOCIOS INTERNACIONALES}

\section{RESUMEN}

El jeitinho brasileño y el guanxi chino se consideran formas indígenas de influencia informal. El primero puede ser descrito como tácticas de comportamiento destinadas a resolver problemas sociales. Este último se describe en términos 
generales como el logro de objetivos mediante el uso de las redes sociales. Estos procesos de influencia fueron elegidos porque son de uso común en las negociaciones comerciales en Brasil y en China. Por lo tanto, entender su peculiaridad es fundamental para la gestión de las organizaciones que participan en negocios en las dos culturas. Así, tratamos de determinar si estos procesos son de diferentes influencias, ya que es posible que un proceso, que se dice que se origina a partir de un contexto cultural particular, también se pueda encontrar en otro lugar. Para investigar su singularidad y la relación entre ellos, se han llevado a cabo dos estudios. En ambos, los participantes evaluaron la representatividad, la tipicidad y la positividad de los escenarios sociales, además de responder una versión de 2I ítems del PVQ, y una escala sobre las actitudes relacionadas con la corrupción. Los datos fueron analizados por una serie de pruebas de diferencias de medias y regresiones jerárquicas, por separado para cada país, y los resultados presentados por muestreo. Había dos muestras: la de los universitarios (con 266 chinos y 220 brasileños) y la de los gerentes (con IOI chinos de Singapur y 246 brasileños). Brasil obtuvo valores significativamente mayores en el ítem de conservación y auto-mejora en comparación con China. Encuestados chinos perciben los escenarios guanxi como más propios de lo que ocurre en China que los escenarios de jeitinho, con un patrón inverso se observa para los brasileños. Aunque los encuestados brasileños evaluaron el jeitinho de manera menos positiva que los escenarios evaluados por los guanxi chinos, los brasileños no percibieron el jeitinho como más positivo que el guanxi. Para las muestras de los gerentes, se observó que los brasileños tuvieron una puntuación significativamente más baja en las actitudes hacia la corrupción en los negocios en comparación con los gerentes chinos. Regresiones jerárquicas sugieren que la positividad está asociada a la corrupción en los negocios para cada respectivo tipo de escenarios por nación.

\section{PALABRAS CLAVE}

Gestión transcultural. Influencia informal. Corrupción. Negocios internacionales. Jeitinho brasileño.

\section{REFERENCES}

Almeida, A. C. (2007). A cabeça do brasileiro. São Paulo: Record.

Amado, G., \& Vinagre Brasil, H. (I99I). Organizational behaviors and cultural context: the Brazilian jeitinho. International Studies of Management and Organization, 21(3), 38-6r.

Aycan, Z. (2008a). Paternalism. In U. Kim, K. S. Yang \& K. K. Hwang (Eds.). Scientific advances in indigenous and cultural psychology: empirical, philosophical and cultural contributions (pp. 445-466). New York: Springer. 
Aycan, Z. (2008b). Cross-cultural approaches to leadership. In P. B. Smith, M. F. Peterson \& D. C. Thomas (Eds.). Handbook of cross-cultural management research (pp. 2I9-238). Thousand Oaks, CA: Sage.

Barbosa, L. (I995). The Brazilian jeitinho: an exercise in national identity. In D. Hess \& R. Da Matta (Eds.). The Brazilian puzzle (pp. 35-46). New York: Columbia University Press.

Barbosa, L. (2006). O jeitinho brasileiro: a arte de ser mais igual do que os outros. São Paulo: Elsevier. Chen, X. P., \& Chen, C. C. (2004). On the intricacies of the Chinese guanxi: a process model of guanxi development. Asia Pacific Journal of Management, 21(3), 305-324.

Chen, Y., Friedman, R., Yu, E., Fang, W., \& Lu, X. (2009). Supervisor-subordinate guanxi: developing a three-dimensional model and scale. Management and Organization Review, 5(3), 375-399. Cheung, M. F. Y., Wu, W-P, Chan, A. K. K., \& Wong, M. M. L. (2009). Supervisor-subordinate guanxi and employee work outcomes: the mediating role of job satisfaction. Journal of Business Ethics, 88(I), 77-89.

Chua, R. Y. J., Morris, M. W., \& Ingram, P. (2009). Guanxi vs networking: distinctive configurations of affect- and cognition-based trust in the networks of Chinese vs American managers. Journal of International Business Studies, 40(3), 490-508.

DaMatta, R. (1997). Carnavais, malandros e heróis: para uma sociologia do dilema brasileiro. São Paulo: Rocco.

Deardorff, D. K. (2009). The Sage handbook of intercultural competence. Thousand Oaks, CA: Sage.

Duarte, F. (2006). Exploring the interpersonal transaction of the Brazilian jeitinho in bureaucratic contexts. Organization, 13(4), 509-527.

Gabrenya, W. K., Jr., \& Hwang, K. K. (1996). Chinese social interaction: harmony and hierarchy on the Good Earth. In M. H. Bond (Ed.). The handbook of Chinese psychology (pp. 309-32I). Hong Kong: Oxford University Press.

Goodenough, W. (I964). Toward a working theory of culture. In R. Borofsky (Ed.). Assessing cultural anthropology (pp. 262-275). New York: McGraw-Hill.

Gregg, G. S. (2005). The Middle East: a cultural psychology. Oxford: Oxford University Press.

House, R. J., Hanges, P. J., Javidan, M., Dorfman, P. W., Gupta, V., \& Globe Associates (2004). Leadership, culture and organizations: the Globe study of 62 nations. Thousand Oaks, CA: Sage.

Hwang, K. K. (I997). Guanxi and mientze: conflict resolution in Chinese society. Intercultural Communication Studies, 7(I), I7-40.

Hwang, K. K., \& Han, K. H. (2010). Face and morality in Confucian society. In M. H. Bond (Ed.), Handbook of Chinese psychology (pp. 479-498). Hong Kong: Oxford University Press.

Johnson, T. P., Kulesa, P., Cho, Y. I., \& Shavitt, S. (2005). The relation between culture and response styles. Journal of Cross-Cultural Psychology, $36(2), 264-277$.

Kobayashi-Hillary, M. (2007). Building a future with Brics: the next decade for offshoring. London: Springer.

Leong, C. H., \& Lin, W. (2009). "Show me the money!" Construct and predictive validation of the intercultural business corruptibility scale. In C. H. Leong \& J. W. Berry (Eds.). Intercultural relations in Asia: migration and work effectiveness (pp. I5I-I76). Singapore: World Scientific.

Liao, Y., \& Bond, M. H. (20II). The dynamics of face loss following interpersonal harm for Chinese and Americans. Journal of Cross-Cultural Psychology, 42(I), 25-38. 
Luo, Y. (2000). Guanxi and business. (Asia-Pacific Business Series I). Singapore: World Scientific. Nitsch, M., \& Diebel, F. (2007). Guanxi economics: Confucius meets Lenin, Keynes, and Schumpeter in contemporary China. Revista de Administração Pública, 41(5), 959-992.

O’Neill, J. (200I). Building better global economic Brics. Global Economics Paper, 66. Retrieved from http://www.goldmansachs.com/our-thinking/archive/archive-pdfs/build-better-brincs.pdf.

Schwartz, S. H. (I992). Universals in the content and structure of values: theoretical advances and empirical tests in 20 countries. In M. P. Zanna (Ed.). Advances in experimental social psychology (pp. I-65). Orlando, FL: Academic Press.

Schwartz, S. H., \& Bardi, A. (200I). Value hierarchies across cultures: taking a similarities perspective. Journal of Cross-Cultural Psychology, 32(3), 268-290.

Schwartz, S. H., Melech, G., Lehmann, A., Burgess, S., Harris, M., \& Owens, V. (200I). Extending the cross-cultural validity of the theory of basic human values with a different method of measurement. Journal of Cross-Cultural Psychology, 32(5), 519-542.

Smith, P. B. (2004). Acquiescent response bias as an aspect of cultural communication style. Journal of Cross-Cultural Psychology, 35(I), 50-6I.

Smith, P. B., Huang, H. J., Harb, C., \& Torres, C. (2012). How distinctive are indigenous ways of achieving influence? A comparative study of guanxi, wasta, jeitinho, and "pulling strings". Journal of Cross-Cultural Psychology, 43(I), I35-I5O.

Tanure, B., \& Duarte, R. G. (2005). Leveraging competitiveness upon national cultural traits: the management of people in Brazilian companies. International Journal of Human Resource Management, 16(12), 220I-22I7.

Teixeira, M. L. M., \& Iwamoto, H. M. (20I3). Padrões culturais avaliativos: Uma análise à luz da taxonomia de Fink (20I2). Cadernos de Gestão Social, 4(2), I99-2I4.

Thomas, A. (I999). Comparison of managing cultural diversity in German-Chinese research and business cooperation. In W. J. Lonner, D. L. Dinnel, D. K. Forgays \& S. A. Hayes (Eds.). Merging past, present, and future in cross-cultural psychology. Selected papers from the Fourteenth International Congress of the International Association for Cross-Cultural Psychology (pp. 520-53I). Lisse: Swets $\&$ Zeitlinger.

Thomas, A., \& Schenk, E. (200I). Beruflich in China. Trainingsprogramm für Manager, Fach- und Führungskräfte. Göttingen: Vandenhoeck \& Ruprecht.

Torres, C. V., \& Dessen, M. A. (2006). The Brazilian jeitinho: Brazil's sub-cultures, its diversity of social contexts, and its family structures. In J. Georgas, J. W. Berry, F. J. R. van de Vijver, C. Kagitçibasi \& Y. H. Poortinga (Eds.). Families across cultures: a 30-nation psychological study (pp. 259-267). Cambridge: Cambridge University Press.

Torres, C. V., \& Dessen, M. A. (2008). Brazilian culture, family, and its ethnic-cultural variety. Arizona Journal of Hispanic Cultural Studies, 12(I), I89-202.

Triandis, H. C. (I994). Cross-cultural industrial and organizational psychology. In H. C. Triandis,

M. D. Dunnette \& L. M. Hough (Eds.). (YEAR) Handbook of industrial and organizational psychology (pp. I03-I72). Palo Alto, CA: Consulting Psychologists Press.

Vercueil, J. (2010). Les pays émergents: Brésil-Russie-Inde-Chine: mutations économiques et nouveaux défis. Paris: Bréal.

Xin, K. R., \& Pearce, J. L. (I996). Guanxi: connections as substitute for formal institutional support. Academy of Management Journal, 39(6), I64I-1658. 
Yan, Y., \& Altman, Y. (2009). Supervisor and subordinate guanxi: a grounded investigation in the People's Republic of China. Journal of Business Ethics, 88, 91-I04.

Yang, K. S. (1957). The concept of Pao as a basis for relations in China. In J. K. Fairbank (Ed.). Chinese thought and institutions (pp. 291-309). Chicago: University of Chicago Press.

Ying, F. (2002). Guanxi's consequences: personal gains at social loss. Journal of Business Ethics, $38(4), 37 \mathrm{I}-380$.

Zamor, C. (2008). Intercultural trainings for German expatriates going to China. Hamburg: Verlag GmbH. 